\title{
Flow cytometric determination of genome size in European seabass (Dicentrarchus labrax), gilthead seabream (Sparus aurata), thinlip mullet (Liza ramada), and European eel (Anguilla anguilla)
}

\author{
Stefano Peruzzi ${ }^{1,2, a}$, Béatrice Chatain ${ }^{1}$ and Bruno Menu ${ }^{1}$ \\ 1 IFREMER, Laboratoire de Recherche Piscicole de Méditerranée, Chemin de Maguelone, 34250 Palavas-les-Flots, France \\ 2 Norwegian College of Fishery Science, University of Troms $\varnothing$, 9037 Troms $\varnothing$, Norway
}

Received 19 December 2003; Accepted 5 July 2004

\begin{abstract}
The nuclear DNA content in Dicentrarchus labrax, Sparus aurata, Liza ramada, and Anguilla anguilla, was measured by flow cytometric analysis. Male human leukocytes were used as internal reference cells. Nucleated fish erythrocytes were stained simultaneously to human leukocytes with a staining buffer containing propidium iodide (PI). Nuclear DNA contents of target species were estimated in relation to an assigned value of $7.0 \mathrm{pg}$ DNA for male human leukocytes. The DNA content/nucleus $( \pm \mathrm{CI})$ was $1.55 \pm 0.02 \mathrm{pg}$ for D. labrax, $1.90 \pm 0.03 \mathrm{pg}$ for S. aurata, $1.57 \pm 0.02 \mathrm{pg}$ for L. ramada, and $2.43 \pm 0.04 \mathrm{pg}$ for A. anguilla. Intraspecific DNA content variations ranged from $0-9 \%$ and averaged around $4 \%$ in all taxa. The results did not evidence significant differences in genome size between males and females in either D. labrax or L. ramada.
\end{abstract}

Key words: DNA content / Teleosts / Dicentrarchus labrax / Sparus aurata / Liza ramada / Anguilla anguilla

\section{Introduction}

Flow cytometry is a well-established method for nuclear DNA content analysis and characterization in experimental biology, and has gained increasing use in fish studies for its rapidity, precision and reproducibility. In fish, which have nucleated erythrocytes, flow cytometric analysis performed on large numbers of fluorescent-stained nuclei has proved to be an ideal tool for various studies including ploidy level determinations (Birstein et al. 1993; Harrell et al. 1995; Van Eenennaam et al. 1996; Lamatsch et al. 2000; Peruzzi and Chatain 2003), genetic stock assessments (Lockwood and Bickham 1991), and ecotoxycological studies (Jenner et al. 1990; Castaño et al. 2000).

The purpose of this study was to estimate by flow cytometry the nuclear DNA content of four teleosts of commercial interest: the European sea bass, Dicentrarchus labrax (Linnaeus 1758) Moronidae; the gilthead seabream, Sparus aurata (Linnaeus 1758), Sparidae; the thinlip mullet, Liza ramada (Risso 1810) Mugilidae, whithin the Perciformes order; and the European eel, Anguilla anguilla (Linnaeus 1758) Anguillidae, within Anguilliformes. Despite the amount of data concerning the genome size of fishes currently published, including some comprehensive studies (Hinegardner 1968;

\footnotetext{
a Corresponding author: stefanop@nfh.uit.no
}

Hinegardner and Rosen 1972; Hardie and Hebert 2003), information concerning these commercially important species is still lacking.

As understanding of genotypic sex is an important tool in aquaculture, the possible presence of sex-specific differences in genome size (DNA content) in two gonochoristic species, sea bass and thinlip mullet, was also investigated. To our best knowledge, this is the first report in which the measurement of nuclear DNA content in specimens of these four teleost fish is analysed by use of flow cytometry.

\section{Material and methods}

Sea bass ( $n=31 ; 16$ males and 15 females) originated from F1 fish of Mediterranean wild stocks held at IFREMER Palavas-les-Flots. Wild seabream $(n=10)$, European eel $(n=10)$, and thinlip mullet $(n=14 ; 9$ males and 5 females) were obtained from local fishermen (Mediterranean Sea, South France). When required, fish species identification was made according to the key characters used by Quéro and Vayne (1997). Fish were brought live to the laboratory and maintained in well-aerated tanks until use. They were then anaesthetised (Eugenol, Cooper, $15 \mathrm{ppm}$ ) and whole blood was drawn by caudal puncture using 2 ml-heparinized syringes. 
The syringes were prepared by repeatedly filling and flushing them out with a Na-heparin solution (100 USP units $\mathrm{ml}^{-1}$ ). Blood samples of approximately $0.1 \mathrm{ml}$ were diluted $(1: 250)$ in 0.1 M PBS ( $\mathrm{pH}=7.5$ ) containing $0.7 \mathrm{mM}$ EDTA (Tiersch et al. 1989a; Alfei et al. 1996) following adjustment with distilled water to the osmotic pressure of $360 \mathrm{mOsm}$. The osmolarity of the diluting medium was chosen according to the range of plasma osmolarities recorded in the analysed species (350-370 mOsm). Osmolarities were measured by use of an automatic micro-osmometer (Autocal 13, ®Roebling). Diluted blood samples were then stored on ice until use. Storage of samples did not exceed 2 hours. Fish were sexed, whenever possible, using non-destructive methods (Peruzzi and Chatain 2000) and returned to their origin. Alternatively, they were sacrificed by an overdose of anaesthetic (50 ppm) and their gonads microscopically checked using wet squash preparations (Guerrero and Shelton 1974).

Blood samples were prepared for propidium iodide (PI) flow cytometric analysis as described by Tiersch et al. (1989b). Fresh male human leukocytes obtained by centrifugation of peripheral blood over a density medium (Ficoll-Paque Plus, Amersham Biosciences) were used as internal standards. Approximately equal aliquots (approx. $20 \mu \mathrm{l}$ ) of each fish and human reference cells were suspended in $0.5 \mathrm{ml}$ of the lysisstaining buffer, mixed and filtered through a $20 \mu \mathrm{m}$ nylon mesh. Prior to analysis, samples were kept at $+4{ }^{\circ} \mathrm{C}$ in the dark for $15 \mathrm{~min}$ to ensure thorough staining of nuclei. In sea bass, male and female blood samples were further analysed as a mixture in order to rule out the possibility of instrumental and/or staining variability (technical variations) capable of masking possible sex differences. For this purpose, additional $n=8$ mixed blood samples from 8 male and 8 female sea bass fish were prepared as above, and run without internal reference cells. The mean DNA content of at least $10^{3}$ cells per sample was measured with a FACScan (Becton Dickinson) flow cytometer and reported in arbitrary units expressed as fluorescence channel numbers (FL2-Area).

Nuclear DNA contents of target species were estimated in relation to an assigned value of $7.0 \mathrm{pg}$ DNA for male human leukocytes (Tiersch et al. 1989a; Ciudad et al. 2002) according to the formula, pg DNA $=7.0 \mathrm{X} / \mathrm{H}$, where $\mathrm{X}$ is the fluorescence channel number of the fish sample and $\mathrm{H}$ the one of male human leukocytes.

Prior to data acquisition, a generic procedure was used to monitor the optical alignment and instrument linearity by use of stabilised chicken erythrocytes (Sigma, R0504) providing peaks for single nuclei, doublets, triplets and a few larger aggregates. Flow cytometer's sensitivity and range were analysed using reference fluorescent beads (Fuoresbrite ${ }^{\mathrm{TM}}$, Polysciences Inc., Warrington, PA, USA). Instrumental and staining variability were determined by repeated analysis of a single sample held on ice over a 1-hour period.

Grubbs' test was used to detect outliers in the data sets in Exploratory Data Analysis (EDA). Hartley's test was employed to test homogeneity of variances between groups. Single-factor analysis of variance (ANOVA) was performed to determine if there were differences in DNA contents between species or between male and female fish within a species. The Scheffe's test was employed to point out differences in mean values. Differences were accepted as significant when $p<0.05$. All means were expressed as values $\pm 95 \%$ confidence interval (CI). Statistical analyses were performed using Statview software.

\section{Results}

Coefficients of variation (CV) of fluorescence peaks from nuclei were routinely $2-4 \%$ when stained with PI. All flow cytometric sample cell distributions were normally distributed and unimodal at all times. The repeated analysis of a single sample held on ice over a 1-hour period revealed a variation of less than $0.1 \%$.

The mean nuclear DNA content was $1.55 \pm 0.02 \mathrm{pg}$ in D. labrax, $1.90 \pm 0.03 \mathrm{pg}$ in $S$. aurata, $1.57 \pm 0.02 \mathrm{pg}$ in L. ramada, and $2.43 \pm 0.04 \mathrm{pg}$ in A. anguilla (Table 1 ). The nuclear DNA content of D. labrax and L. ramada were not significantly different from one another and $35 \%$ lower than the one of $S$. aurata, itself being $28 \%$ lower than the one of A. anguilla $(F=887.1 ; p=0.0001 ; n=3$ and 46). A graphic representation of typical fluorescence histograms obtained from target fish erythrocytes and human leukocytes are reported in Figures 1a-d. Intraspecific individual nuclear DNA content variations ranged from $0-9 \%$ and averaged around $4 \%$ in all taxa (Fig. 2).

For sea bass, no significant differences in DNA content were found between male and female fish $(F=0.512 ; p=$ $0.487 ; n=1$ and 13). Mean DNA content in both male and female mullet was $1.57 \mathrm{pg}(F=0.009 ; p=0.925 ; n=1$ and 12). The supplementary analysis of mixed blood samples in sea bass yielded single fluorescence peaks at all times (mean channel number $\pm \mathrm{CI}=206.6 \pm 6.2$ ). European eel specimens were juvenile forms and could not be sexed. Seabream specimens were not considered since the species is a protandrous hermaphrodite.

\section{Discussion}

Comprehensive reports on the genome size of teleost fish have been published in the past (Hinegardner 1968; Hinegardner and Rosen 1972). Recently, Hardie and Hebert (2003) observing the relationships between nucleus, cell and genome size in fish reported the DNA content of 22 cartilaginous and 201 ray-finned species. Despite this amount of data, information is still lacking concerning the four teleosts analysed in the present study.

The four species hereby examined had a nuclear DNA content ranging from $1.56 \mathrm{pg} /$ nucleus, in sea bass and thinlip mullet, to $2.43 \mathrm{pg} /$ nucleus in the European eel. Generally, all these values are common among Perciformes and other ray-finned teleosts including different species of Moronidae, Mugilidae and Anguillidae (Hardie and Hebert 2003). These last authors reported values of $1.90 \mathrm{pg} /$ nucleus in Morone saxatilis, 1.55 and $1.68 \mathrm{pg} /$ nucleus in two species of mullets (Liza vaigiensis and Myxus elongatus), and $2.03 \mathrm{pg} /$ nucleus in Anguilla rostrata measured using Feulgen stain preparations. Finally, Cano et al. (1981) reported the DNA content of 6 species of Sparidae resulting in values from 1.04 to $1.30 \mathrm{pg} /$ nucleus. 

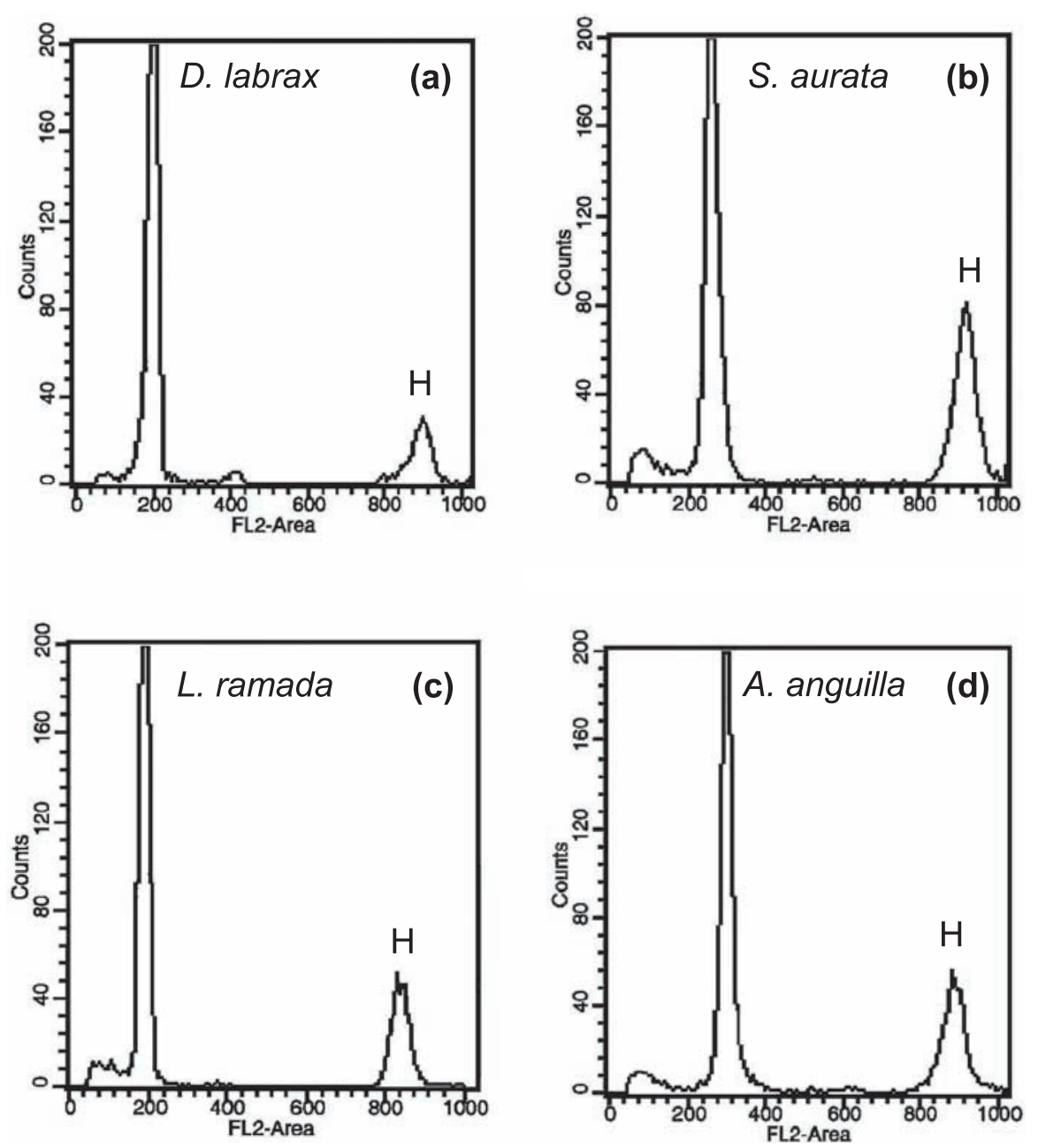

Fig. 1. Flow cytometric DNA content distribution of D. labrax (a), S. aurata (b), L. ramada (c), A. anguilla (d) erythrocytes (first peak), and standard human leukocytes (H). DNA values are reported in arbitrary units expressed as fluorescence channel numbers (FL2-Area).

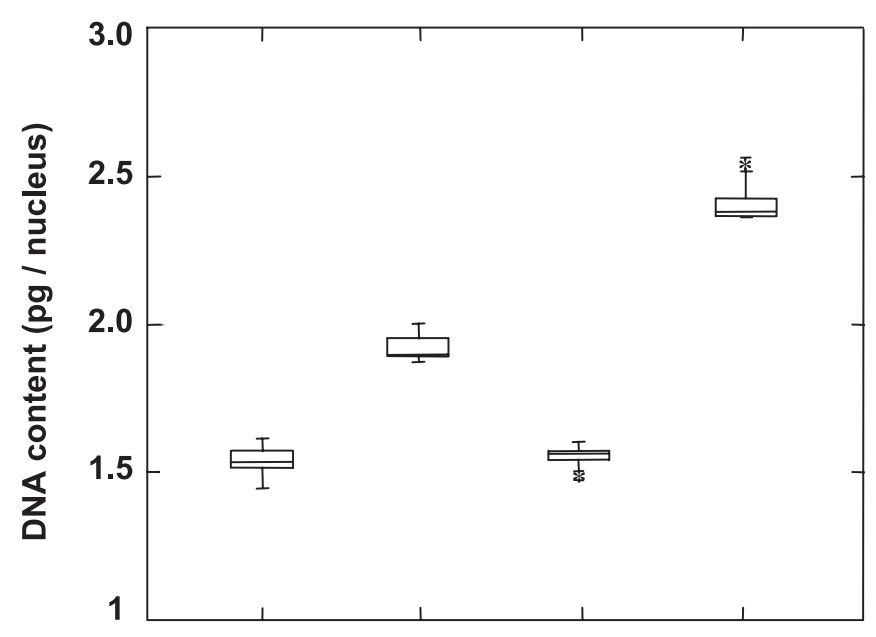

D. labrax S. aurata $L$. ramada A. anguilla

Fig. 2. Intraspecific DNA content variations in D. labrax $(n=15)$, S. aurata $(n=10)$, L. ramada $(n=14)$ and A. anguilla $(n=10)$. Median, upper and lower values, and interquartile ranges are shown. Asterisks indicate mild outliers ( $n=1$ in L. ramada and $n=2$ in A. anguilla).
The only published report on DNA content in the species under examination is found for A. anguilla by Sola and coworkers (1984). These authors reported a mean value of $3.20 \mathrm{pg} /$ nucleus for a limited number of erythrocytes $(n=40)$ measured by histophotometry in this species. This represents a difference of $32 \%$ compared to our results obtained by flow cytometry on 10000 cells/individual. Similar variability in results between the traditional fluorometry and photometry methods and current flow cytometric techniques has been reported for other species by Ciudad et al. (2002). These last authors point out also the variability induced by the use of preferential binding dyes (e.g. DAPI for AT-rich DNA sequences) or DNA intercalating dyes such as PI, and the use of different species as reference standards in flow cytometric measurements. Finally, they privileged the use of a single standard (e.g. human blood leukocytes) as a mean to limit the variability induced by the addition of a second reference, like chicken erythrocytes, for which the mean DNA content reports are not always consistent (Ciudad et al. 2002).

In our work, a comparison of chromosome numbers among the analysed fish cannot explain any of the observed differences in nuclear DNA values. The three Perciformes species 
Table 1. Nuclear DNA content of D. labrax, S. aurata, L. ramada, A. anguilla and reference male human cells.

\begin{tabular}{|c|c|c|c|}
\hline Species & Sex & $\begin{array}{c}\text { Mean DNA } \\
\text { content } \\
\text { (pg/nucleus) }\end{array}$ & $\mathrm{CV}$ \\
\hline Dicentrarchus & $\mathrm{M}$ & 1.55 & 3.89 \\
\hline \multirow[t]{14}{*}{ labrax } & M & 1.59 & 3.68 \\
\hline & M & 1.54 & 3.67 \\
\hline & M & 1.53 & 3.08 \\
\hline & M & 1.53 & 3.69 \\
\hline & M & 1.53 & 3.80 \\
\hline & M & 1.63 & 3.45 \\
\hline & M & 1.58 & 3.06 \\
\hline & $\mathrm{F}$ & 1.59 & 3.73 \\
\hline & $\mathrm{F}$ & 1.53 & 4.01 \\
\hline & $\mathrm{F}$ & 1.61 & 3.20 \\
\hline & $\mathrm{F}$ & 1.55 & 3.25 \\
\hline & $\mathrm{F}$ & 1.55 & 2.89 \\
\hline & $\mathrm{F}$ & 1.46 & 2.46 \\
\hline & $\mathrm{F}$ & 1.53 & 3.01 \\
\hline \multirow[t]{2}{*}{ Mean value \pm CI } & & $1.55 \pm 0.02$ & \\
\hline & - & 1.96 & 3.13 \\
\hline \multirow[t]{9}{*}{ Sparus aurata } & - & 1.89 & 3.56 \\
\hline & - & 1.99 & 3.16 \\
\hline & - & 1.88 & 3.25 \\
\hline & - & 1.88 & 3.39 \\
\hline & - & 1.94 & 3.98 \\
\hline & - & 1.88 & 3.41 \\
\hline & - & 1.86 & 4.20 \\
\hline & - & 1.89 & 3.43 \\
\hline & - & 1.86 & 3.68 \\
\hline \multirow[t]{2}{*}{ Mean value \pm CI } & & $1.90 \pm 0.03$ & \\
\hline & M & 1.50 & 3.96 \\
\hline \multirow[t]{13}{*}{ Liza ramada } & M & 1.58 & 3.92 \\
\hline & M & 1.58 & 2.53 \\
\hline & M & 1.57 & 2.47 \\
\hline & M & 1.60 & 2.59 \\
\hline & M & 1.59 & 2.98 \\
\hline & M & 1.62 & 2.37 \\
\hline & M & 1.55 & 3.61 \\
\hline & M & 1.56 & 3.60 \\
\hline & $\mathrm{F}$ & 1.58 & 3.63 \\
\hline & $\mathrm{F}$ & 1.58 & 3.52 \\
\hline & $\mathrm{F}$ & 1.52 & 2.46 \\
\hline & $\mathrm{F}$ & 1.59 & 3.88 \\
\hline & $\mathrm{F}$ & 1.60 & 2.38 \\
\hline \multirow[t]{2}{*}{ Mean value \pm CI } & & $1.57 \pm 0.02$ & \\
\hline & - & 2.38 & 3.39 \\
\hline \multirow[t]{9}{*}{ Anguilla anguilla } & - & 2.39 & 3.42 \\
\hline & - & 2.38 & 3.99 \\
\hline & - & 2.38 & 3.93 \\
\hline & - & 2.39 & 3.36 \\
\hline & - & 2.55 & 2.31 \\
\hline & - & 2.40 & 3.49 \\
\hline & - & 2.56 & 2.04 \\
\hline & - & 2.40 & 3.30 \\
\hline & - & 2.44 & 3.78 \\
\hline Mean value $\pm \mathrm{CI}$ & & $2.43 \pm 0.04$ & \\
\hline Human leukocytes & $\mathbf{M}$ & $7.00 \pm \mathbf{0 . 0 3}$ & \\
\hline
\end{tabular}

hereby examined posses a diploid number of $2 n=48$ chromosomes (Cataudella et al. 1973; Sola and Cataudella 1978). This is not surprising as these and many other marine teleosts belonging to this group show little divergence in both chromosome number and structure (Galetti et al. 2000). The European eel's karyotype is instead composed of $2 n=38$ chromosomes (Chiarelli et al. 1969).

In this work, intraspecific individual nuclear DNA content variations ranged from zero to $9 \%$ in all taxa. Such level of genome size variation between individuals within populations has been reported for other fish species in the past (Cui et al. 1991; Lockwood and Derr 1992; Carvalho et al. 1998). The presence of few outliers partially responsible for the observed variation in $L$. ramada and A. anguilla did not affect the overall results. These values could be the related to natural variation within the analysed species, as well as to technique-related factors. Nevertheless, instrumental and methodological shifts were not observed during any of the technical verifications.

Flow cytometric analysis has proved to be a sensitive method for detecting sex-related differences in various organisms, including fish (Tiersch et al. 1989b; Alfei et al. 1996). In the present work, no measurable sex differences in DNA content were found in either sea bass or mullet specimens. European eel specimens revealed to be sexually immature and their sex could not be assessed with certitude. Despite the carefully controlled and standardized conditions of sample preparation, our analysis did not reveal significant gender-like variations. In sea bass, male and female blood samples were first compared individually and then as a mixture in order to rule out the possibility of instrumental and/or staining variability (technical variations) capable of masking possible differences. As expected, this further analysis only confirmed the absence of instrumental and methodological shifts. Overall, this is in agreement with previous reports reviewed by Zanuy et al. (2001) showing also the lack of sex-specific DNA sequences or morphologically differentiated sex chromosomes in sea bass. To date, only the work by Cano et al. (1996) suggests the presence of sex-chromosome variations in this species involving the amount and pattern of heterochromatin distribution (C-bands). In A. anguilla, Wiberg (1983) reported the absence of cytological evident sex-chromosomes and sex-specific nucleolar organizer regions (NORs). Lack of cytogenetics differences between male and female fish were also reported for L. ramada by Rossi et al. (1997).

In conclusion, this work fills a gap in the literature providing information on the genome size of four important teleosts using a single and standardized technique. Finally, it shows the absence of measurable nuclear DNA variations between male and female fish in D. labrax and L. ramada supporting other results obtained at molecular or cytogenetics level.

Acknowledgements. The authors wish to thank Christophe Duperray, Director of the "Service Régional de Cytométrie en Flux du Languedoc-Roussillon" (INSERM U291, Montpellier, France) for his valuable help at flow cytometry. Christian Fauvel (IFREMER, Palavas-les-Flots) is gratefully acknowledged for his contribution. This study was partly supported by the European Community Access to Research Infrastructures/Action of the Improving Human Potential Programme - ASEFAF Project (Contract NR. HPRI-CT2001-00146). 


\section{References}

Alfei L., Cavallo D., Eleuteri P., Grollino M.G., Colombari P.T., Ferri A., Onali A., De Vita R., 1996, Nuclear DNA content in Salmo fibreni in Lake Posta Fibreno, Italy. J. Fish Biol. 48, 1051-1058.

Birstein V.J., Poletaev A.I., Goncharov B.F., 1993, DNA content in Eurasian sturgeon species determined by flow cytometry. Cytometry 14, 377-383.

Cano J., Thode G., Alvarez M.C., 1981, Analisis cariologico de seis especies de esparidos del Mediterraneo. Genet. Iber. 33, 181-188.

Cano J., Pretel A., Melendez S., Garcia F., Caputo V., Fenocchio A.S., Bertollo L.A.C., 1996, Determination of early stages of sex chromosome differentiation in the sea bass Dicentrarchus labrax L. (Pisces: Perciformes). Cytobios 87, 45-59.

Carvalho M.L., Oliveira C., Foresti F., 1998, Nuclear DNA content of thirty species of neotropical fishes. Genet. Mol. Biol. 21, 47-54.

Castaño A., Sanchez P., Llorente M.T., Carballo M., de la Torre A., Muñoz M.J., 2000, The use of alternative systems for the ecotoxicological screening of complex mixtures on fish populations. Sci. Total Environ. 247, 337-348.

Cataudella S., Civitelli M.V., Capanna E., 1973, The chromosomes of some Mediterranean teleosts: Scorpaenidae, Serranidae, Labridae, Blenniidae, Gobiidae (Pisces-Scorpaeniformes, Perciformes). Boll. Zool. 40, 385-389.

Chiarelli B., Ferrantelli O., Cucchi C., 1969, The karyotype of some teleostean fish obtained by tissue culture in vitro. Experientia 25, 426-427.

Ciudad J., Cid E., Velasco A., Lara J.M., Aijón J., Orfao A., 2002, Flow cytometry measurement of the DNA contents of G0/G1 diploid cells from three different teleost fish species. Cytometry 48, 20-25.

Cui J., Ren X., Yu Q., 1991, Nuclear DNA content variation in fishes. Cytologia 56, 425-429.

Galetti Jr. P.M., Aguilar C.T., Molina W.F., 2000, An overview of marine fish cytogenetics. Hydrobiologia 420, 55-62.

Guerrero R.D., Shelton W.L., 1974, An aceto-carmine squash method of sexing juveniles fishes. Progress. Fish Cult. 36, 56.

Hardie D.C., Hebert P.D.N., 2003, The nucleotypic effects of cellular DNA content in cartilaginous and ray-finned fishes. Genome 46, 683-706.

Harrell R.M., Van Heukelem W., Kerby J.H., 1995, Triploid induction validation techniques: A comparison of karyotyping, flow cytometry, particle size analysis and staining nucleolar organizer regions. Aquaculture 137, 159-160.

Hinegardner R., 1968, Evolution of cellular DNA content in Teleost fishes. Am. Nat. 102 (928), 517-523.

Hinegardner R., Rosen D.E., 1972, Cellular DNA content and the evolution of Teleostean fishes. Am. Nat. 106 (951), 621-644.
Jenner N.K., Ostrander G.K., Kavanagh T.J., Livesey J.C., Shen M.W., Kim S.C., Holmes E.H., 1990, A flow cytometric comparison of DNA content and glutathione levels in hepatocytes of English sole (Parophyrs vetulus) from areas of differing water quality. Arch. Environ. Contamin. Toxicol. 19, 807-815.

Lamatsch D.K., Steinlein C., Schmid M., Schartl M., 2000, Non-invasive determination of genome size and ploidy level in fishes by flow cytometry: detection of triploid Poecilia formosa. Cytometry 39, 91-95.

Lockwood S.F., Bickham J.W., 1991, Genetic stock assessment of spawning arctic cisco (Coregonus autumnalis) populations by flow cytometric determination of DNA content. Cytometry 12, 260-267.

Lockwood S.F., Derr J.N., 1992, Intra and inter-specific genome-size variation in the Salmonidae. Cytogen. Cell Genet. 59, 303-306.

Peruzzi S., Chatain B., 2000, Pressure and cold shock induction of meiotic gynogenesis and triploidy in the European sea bass (Dicentrarchus labrax L.). Aquaculture 189, 23-37.

Peruzzi S., Chatain B., 2003, Induction of tetraploid gynogenesis in the European sea bass (Dicentrarchus labrax L.). Genetica 119, 225-228.

Quéro J.C., Vayne J.J., 1997, Les poissons de mer des pêches françaises. Delachaux et Niestlé Edn., Lausanne, Switzerland.

Rossi A.R., Gornung E., Crosetti D., 1997, Cytogenetic analysis of Liza ramada (Pisces, Perciformes) by different staining techniques and fluorescent in situ hybridization. Heredity 79, 83-87.

Sola L., Cataudella S., 1978, Prime osservazioni sulla cariologia degli sparidi Mediterranei. Boll. Zool. 45, 242.

Sola L., Camerini B., Cataudella S., 1984, Cytogenetics of Atlantic eels: C- and G-banding, nucleolus organizer regions, and DNA content. Cytogenet. Cell Genet. 38, 206-210.

Tiersch T.R., Chandler R.W., Wachtel S.S., Elias S., 1989a, Reference standards for flow cytometry and application in comparative studies of nuclear DNA content. Cytometry 10, 706-710.

Tiersch T.R., Chandler R.W., Kallman K., Wachtel S.S., 1989b, Estimation of nuclear DNA content by flow cytometry in fishes of the genus Xiphophorus. Comp. Biochem. Physiol. B 94, 465-468.

Van Eenennaam A.L., Van Eenennaam J.P., Medrano J.F., Doroshov S.I., 1996, Rapid verification of meiotic gynogenesis and polyploidy in white sturgeon (Acipenser transmontanus Richardson). Aquaculture 147, 177-189.

Wiberg U.H., 1983, Sex determination in the European eel (Anguilla anguilla L.). Cytogenet. Cell Genet. 36, 589-598.

Zanuy S., Carrillo M., Felip A., Rodríguez L., Blázquez M., Ramos J., Piferrer F., 2001, Genetic, hormonal and environmental approaches for the control of reproduction in the European sea bass (Dicentrarchus labrax L.). Aquaculture 202, 187-203. 